\title{
膝前十字勒帯新鮮損傷に対する一次修復術の治療成績
}

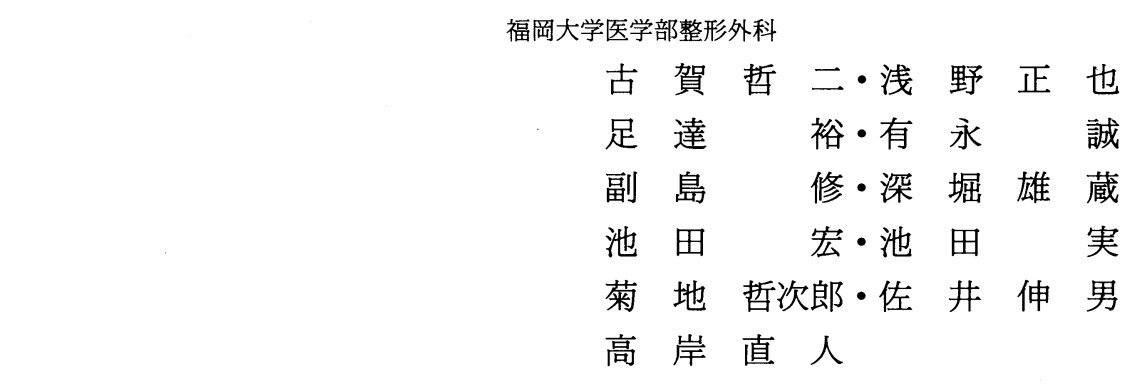

\section{Follow-up Study of Primary Repair for the Acutely Torn Anterior Cruciate Ligament}

by

Tetsuji Koga, Masaya Asano, Yutaka Adachi, Makoto Arinaga, Osamu Soejima, Yuzou Fukahori, Hiroshi Ikeda, Minoru Ikeda, Tetsujiro Kikuchi, Nobuo Sai and Nahoto Takagishi

Department of Orthopaedic Surgery, School of Medicine, Fukuoka University, Fukuoka, Japan

Fifteen patients who underwent primary repair of the acutely torn anterior cruciate ligament (ACL) were followed and short-term results were estimated. The subjects were 12 men and 3 women. Combined ligamentous injuries consisted of medial collateral ligament tear in 4 knees, posterior cruciate ligament tear and others tear in 5 kness. Follow-up term ranged from 12 to 40 months, with the average of 20.9 months. All patients were evaluated subjectively and objectively by Kobayashi scoring system. Most of the patients with an isolated ACL tear had good results. However, it was difficult to have good results in both ROM and stability.

\section{はじめに}

スポーツおよび交通事故による滕外傷が増加してい る現在，急性期に損傷された膝の病態を正しく把握し 適切な治療を行うことは言うまでもない.しかし前十 字勒帯 (以下 $\mathrm{ACL}$ ) 新鮮損傷に対する治療に関する報 告はさまざまで，いまだ問題を残しているように思わ れる.われわれは, 昭和 60 年より ACL 新鮮損傷を 32 症例経験し, この内一次修復術を施行した症例に対し 術後成績を調査した。

\section{対象および方法}

昭和 60 年 1 月より昭和 63 年 7 月までに, ACL 新鮮 損傷の一次修復術を 19 例に施行し, この内一年以上経 過し直接検診出来た症例は 15 例 15 膝であった。男性 11 膝, 女性 4 滕, 手術時年令は 17 才から 58 才まで平 均 27.8 才, 経過観察期間は 12 力月から 40 力月で平均 20.9 カ月である。受傷から手術までの期間は 0 日から 17 日で, 平均 10.3 日であった。合併損傷の有無につい てみると, ACL 単独損傷 (以下 A群) は 6 滕, ACL お よび内側々副勒帯損傷 (以下 AM 群) は 4 膝, ACL に 後十字靱帯損傷を合併したもの（以下 AP 群）が 5 膝 であった(表 1 ). 半月損傷の合併は 4 膝にみられ，外 
表 1 合併鞀帯損傷

\begin{tabular}{|c|c|c|c|c|}
\hline A & 群 & A C L & 6 & 膝 \\
\hline A $\mathrm{M}$ & 群 & $\mathrm{ACL}+\mathrm{MCL}$ & 4 & 膝 \\
\hline A $P$ & 群 & $\begin{array}{l}A C L+P C L \\
A C L+P C L+M C L \\
A C L+P C L+L C L \\
A C L+P C L+M C L+L C L\end{array}$ & $\begin{array}{l}1 \\
2 \\
1 \\
1\end{array}$ & $\begin{array}{l}\text { 膝 } \\
\text { 膝 } \\
\text { 膝 } \\
\text { 膝 }\end{array}$ \\
\hline
\end{tabular}

表 2 受傷原 因

\begin{tabular}{|c|c|}
\hline $\begin{array}{l}\text { スポーツ外傷 } \\
\text { ラグビー } \\
\text { アメリカンフットボール } \\
\text { バスケットボール } \\
\text { ソフトボール } \\
\text { ハンドボール } \\
\text { 柔 道 } \\
\text { 交通外 傷 } \\
\text { の 他 外傷 }\end{array}$ & $\begin{array}{l}2 \\
1 \\
1 \\
1 \\
1 \\
1\end{array}$ \\
\hline 計 & 15膝 \\
\hline
\end{tabular}

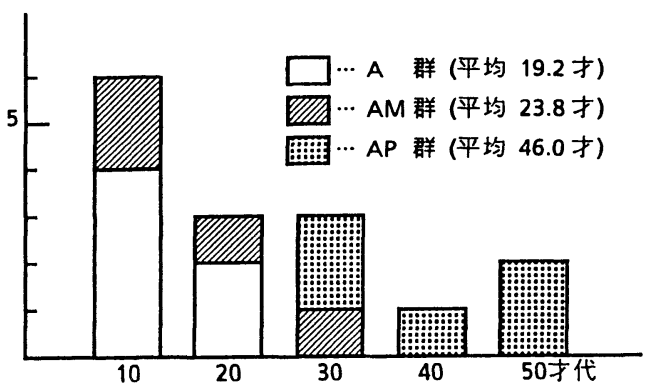

図 1 年令分布

側半月損傷は 3 膝, 両側半月損傷は 1 膝であった。受 傷原因はスポーツ外傷が 7 膝, 交通外傷が 7 膝, 転落 事故が 1 膝で, AP 群はすべて事故による外傷であった (表 2 ). 年令分布は 10 才代がもっとも多く, 各群の 平均は AP 群がもっとも高令であった(図 1). ACL 断 裂部位は近位部 6 膝, 中央部 5 膝, 遠位部 4 膝であり, 中央部断裂は $\mathrm{A}$ 群には存在しなかった。断裂形態は完 全断裂例が 9 滕, 不全断裂例が 6 膝であった。一次修 復術は簡易 Bunell 法か Marshall 法で大腿骨または脛 骨に pull out 縫合を行った. 固定肢位は全例 $30^{\circ}$ 屈曲 位で, 術後 2 週〜 7 週, 平均 5.5 週の固定を行い, そ の後凌装具に変更し荷重開始は $6 \sim 10$ 週であった.

調査内容は, 小林 ${ }^{4)}$ の評価法による自覚的, 他賞的評 価を行い, 徒手検査として前方引出しテスト (ADT), Lachman test, N-test を行った.さらに 14 例に, knee

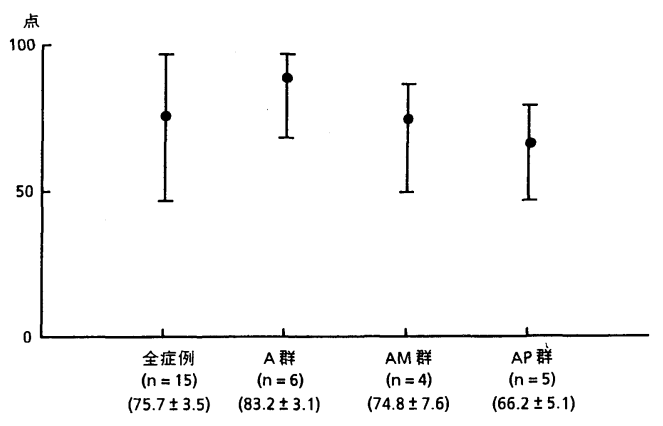

図 2 総合評価(小林の評価法)

表 3 自 賞的評価

\begin{tabular}{|c|c|c|c|c|c|}
\hline & $\begin{array}{l}\text { 10点 } \\
\text { (膝) }\end{array}$ & $\begin{array}{l}7 \text { 点 } \\
\text { (膝) }\end{array}$ & $\begin{array}{l}5 \text { 点 } \\
\text { (膝) }\end{array}$ & $\begin{array}{l}3 \text { 点 } \\
\text { (膝) }\end{array}$ & $\begin{array}{l}0 \text { 点 } \\
\text { (膝) }\end{array}$ \\
\hline 不安定感 & 11 & - & 2 & 2 & 0 \\
\hline Giving Way & 13 & - & 1 & 1 & 0 \\
\hline 疼痛 & 8 & 5 & 1 & 1 & 0 \\
\hline 腫脹 & - & - & 9 & 2 & 4 \\
\hline 階段昇降 & - & - & 12 & 4 & 0 \\
\hline 歩行能力 & 12 & - & 4 & 0 & 0 \\
\hline 日 常 活 動 & 7 & - & 6 & 2 & 0 \\
\hline 満 足 度 & 0 & 2 & - & 10 & 3 \\
\hline
\end{tabular}

laxity tester による前方動摇性の測定, cybex による 筋力評価を行った。術前に何らかのスポーツを行って いた 13 例についてはスポーツ復帰状況を調査した。

\section{結果}

小林の総合評価で 80 点以上のものは 5 例 (33.3\%), 60 点以下のものが 2 点 (13.3\%) で, 平均 75.7 点で あった。各群を比較すると A 群は AP 群に有意の差を もって高得点を示した（ $\mathrm{p}<0.025 ）$ (図 2$)$.

自覚的評価で各項目についてみると, これらの自覚 症状をまったく有しないものは $\mathrm{A}$ 群で 6 例中 3 例, $\mathrm{AM}$ 群では 4 例中 1 例に認められたが, AP 群の 5 例すべて に何らかの症状を有していた. giving way を訴えるも のは, AM 群の 1 例と $\mathrm{AP}$ 群の例であり, それらの成 績は不良であった。 日常活動では, まったく支障がな いか，またはほほ普通どうりのものが 13 例 (86.7\%) であった．現在の満足度は，かなり満足と答えたもの が 2 例，まあまあ満足と答えたものが 10 例で合計 $80 \%$ 
表 4 他 覚 的 評 価

\begin{tabular}{|c|c|}
\hline $\begin{array}{l}\text { 前方引き出し } \\
\text { ストレス } \mathrm{X} \text { 線 }\end{array}$ & $\begin{array}{l}-3 \mathrm{~mm} \sim 7 \mathrm{~mm} \\
\text { 平 均 } 3.1 \pm 0.7 \mathrm{~mm}\end{array}$ \\
\hline $\begin{array}{lll}\mathrm{R} & \mathrm{O} & \mathrm{M}\end{array}$ & 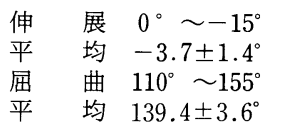 \\
\hline 大 䬶 筋 萎 縮 & $\begin{array}{l}5 \mathrm{~cm}:-4.3 \mathrm{~cm} \sim+0.1 \mathrm{~cm} \\
\text { 平 均 }-2.0 \pm 0.3 \mathrm{~cm} \\
10 \mathrm{~cm}:-4.6 \mathrm{~cm} \sim+0.8 \mathrm{~cm} \\
\text { 平 均 }-2.5 \pm 0.4 \mathrm{~cm}\end{array}$ \\
\hline $\mathrm{X}$ 線的 $\mathrm{OA}$ 変化 & $\begin{array}{ll}8 \text { 例 } & 53 \% \\
4 \text { 例 } & 27 \% \\
3 \text { 例 } & 20 \%\end{array}$ \\
\hline
\end{tabular}

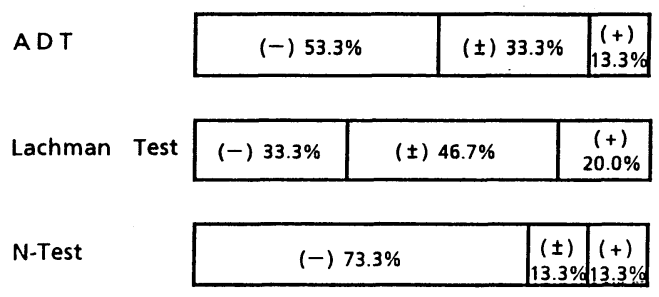

図 3 徒手検查

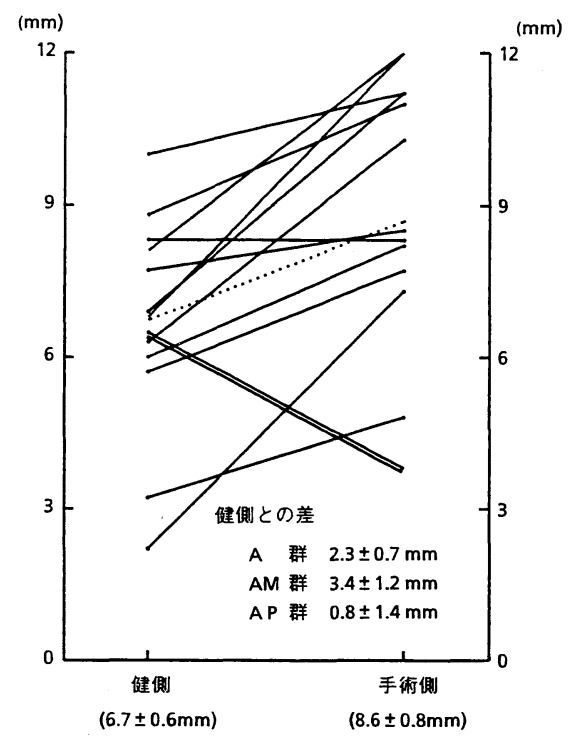

図 4 Knee Laxity Testerによる前方移動量 $(\mathrm{n}=$ 14)

であったが，すべて満足していると答えたものはいな かった, また不満が 3 例あり正座が出来ないことや giving way の存在がその理由であった（表 3 ).

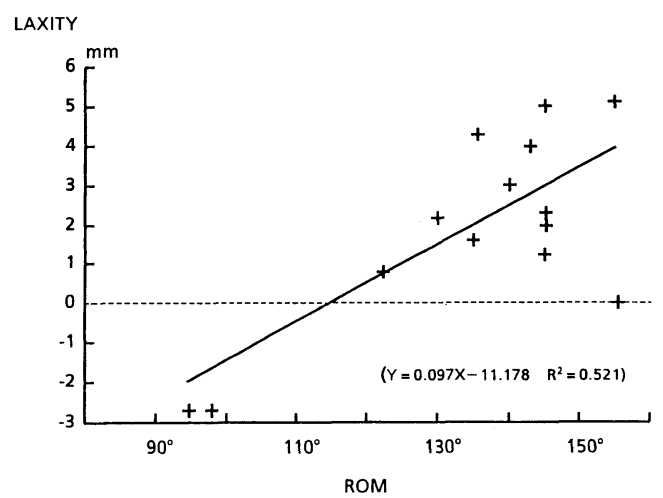

図 5 可動域と前方移動量の比較

他覚的評価で, 可動域に関しては, $10^{\circ}$ 以上の伸展制 限が 3 膝あり,この内 2 膝は $120^{\circ}$ 未満の可動域制限を きたしたもので，これらはすべて AP 群であった。可 動域制限が強く術後瘾着剥離などを行ったものは 3 膝 あった，正座が可能なものは 6 例 (40\%) であった。 $\mathrm{X}$ 線的には, 術前と比較し明らかな OA 変化を 3 膝に, 膝蓋骨低位を 3 膝に認めた（表 4 ）.

徒手検査に関しては，(-)例が ADT で 8 膝（53.3 \%), Lachman test で 5 膝 $(33.3 \%), \mathrm{N}$-test で 11 膝 (73.3\%) に認められた。 N-test 陽性例は 2 例 (13.3 \%)でそれらは AM 群と AP 群で評価点はもっとも低 かった(図 3 ). 前方動摇性はストライカー社製の knee laxity tester を用いて, 健側と手術側を比較した. AP 群の動摇性が低いのは, 関節拘縮の影響と思われ，こ れらは評価点が低いにもかかわらず，徒手検査陰性例 も多く,また可動域に関しても悪い症例が多い(図 4). 可動域と動摇性の関係を見ると可動域が大きいほど, 動摇性が増す傾向にあったが不全断裂例で両者, 健側 との差を認めない症例もあった（図 5 ). 筋力評価は Cybex 340 を用いて $60 \mathrm{deg} / \mathrm{sec} て ゙$ 測定した大腿四頭 筋, 膝屈筋の最大トルク值を健側に対する割合いで表 した．膝屈筋々力は大腿四頭筋々力に比べ筋力低下は 少なかった (図 6 )。また大腿四頭筋々力は総合評価点 と相関を認めた（ $\mathrm{p}<0.005)$. 手術前に何らかのスポ ーツを行っていたもの 13 例のスポーツ復帰状況は, 13 例中 8 例 $(61.5 \%)$ が元のスポーツレベルへ復帰して いた．各群をみるとA群は 5 例(83.3\%), AM 群は 2 例 $(50 \%)$, AP 群は 1 例 $(33.3 \%)$ が元のスポーツへ 復帰していた。スポーツ不可能となった 3 例はいずれ も可動域が悪く, 筋力低下が著明な症例であった（図 


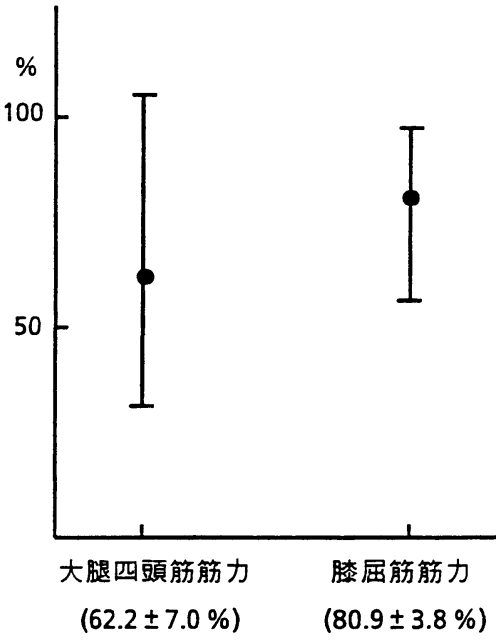

図 6 筋力評価

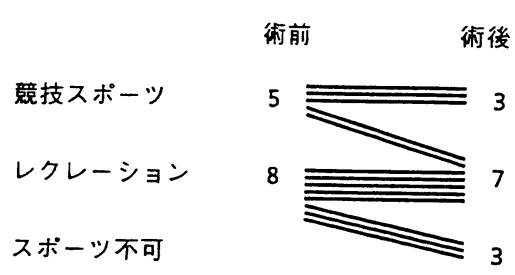

図 7 スポーツ復帰状況 $(n=13)$

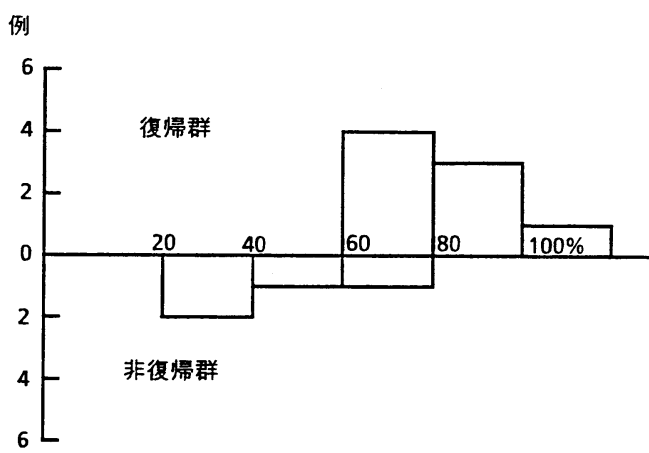

図 8-1 スポーツ復㷌と大腿四頭筋筋力

7 ).スポーツ復帰状況と大腿四頭筋々力の関係は復帰 群では平均 $78.6 \pm 5.3 \%$ あ゙あのに対し，非復帰群は 平均 $44.5 \pm 6.5 \%$ \%あった。 また競技スポーツへ復帰 したものは平均 $85 \pm 8.5 \%$ で健側を上回った症例が 1 例ありこれは国体選手として復帰している(図 8-1). スポーツ復㷌と膝屈筋々力の関係では, 復帰群の平均 は $88.3 \pm 3.9 \%$ で, 非復帰群は $71.0 \pm 6.3 \%$ あっった, 競技スポーツに復帰した者はすべて $90 \%$ 以上に回復し

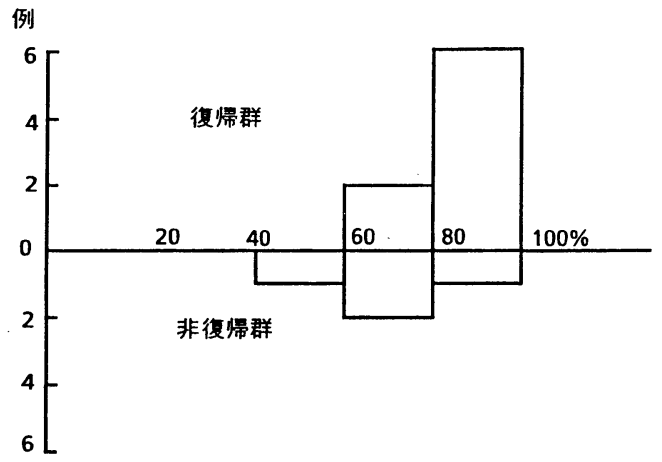

図 8-2 スポーツ復帰と膝屈筋筋力

ていた（図 $8-2$ ).

考

察

1950 年 O’Donoghue ${ }^{6 / 7) 899)}$ によって膝靶帯新鮮損傷 に対する一次修復術のすぐれた治療成績が発表されて 以来, 膝勒帯損傷に対しては一次修復術が広く行われ るようになった. 著者らの短期成績では ACL 単独損傷 例の成績はほぼ良好であったが, PCL 損傷を合併した 複合勒带損傷例に成績不良例が多かった。良好な可動 域が得られても不安定性の残存を認める症例があり, 同時に満足する症例は少なかった，従来より大腿四頭 筋は ACL に対し antagonist と言われており, 術後早 期の積極的な訓練は避けるとする考え方があり，また 膝屈筋群の強力な訓練が術後膝を安定させると言われ ていた，今回の調査では, 大腿四頭筋々力が術後の評 価点と相関を認めており, 術療法の難しさを痛感させ られた. ACL 新鮮損傷例に対する, 手術適応について は，いまだ議論が分れている，われわれは，中高年者 で活動性が低い場合, 複合鞁帯損傷以外には保存的治 療を行い, 活動性の高い若年者に対しては, 例え ACL 単独損傷例においても積極的に観血的治療を行ってい る.

しかし一次修復術がどこまで期待できるか，断裂し た線維が一次修復で確実に癒合し ACL として充分な機 能を有するかどうか, Cabaud ら ${ }^{1) 2)}$ の猿の実験では ACL の一次修復術 4 力月後の引張り強度は, 大腿骨側では, 正常 ACL の $47 \%$, 脛骨側では $63 \%$ と報告している. 緒方ら ${ }^{10)}$ は犬の ACL, MCL を一次修復し早期運動群 と固定群に分け 12 週で観察した結果, 早期運動群の全 例に ACL は消失していたと報告している.今回の調査 で, 可動域が良好な症例は動摇性が強い傾向にあった。 
術後平均 5.5 週の固定を行っており, これは, (1)縫合 部の強度が不十分なうちに可動域改善を行ったのが原 因なのか. (2)完全断裂した ACL を元の解剖学的な線維 方向に修復するのは不可能で, 縫合された ACL は一本 の紐状となる, したがって可動域が改善するにつれて 緩みが生ずる結果となった, など推察される.しかし, (2)に関して不全断裂例は完全断裂例に比べ, 解剖学的 に近い状態に修復が可能ともいる. 著者らの小経験に てらし合せて考えた場合, 一次修復術でもっとも良い 成績が得られるものは, 不全断裂例ではないかと推測 できる.

$$
\text { おわりに }
$$

前十字勒带新鮮損傷に対し一次修復術を施行した 15 人 15 膝の短期成績を報告した.

\section{参考 文 献}

1) Cabaud, H. E. et al.: Acute anterior cruciate ligament injury and augmented repair. Am. J. Sports. Med. 8: 395-401, 1980.

2) Cabaud, H.E. et al.: Experimental studies of acute anterior cruciate ligament injury and repair. Am. J. sports. Med. 7 : 18-21, 1979.

3) Glove, P. et al.: Non-operative treatment of the torn anterior cruciate ligament. J. Bone Joint Surg. 65-A : 184-192, 1983.

4) 小林 晶: 膝勒帯損傷における非手術例の予後. 臨整 外, $22: 35-47,1987$.

5) Odensten, M. et al. : The course of partical anterior cruciate ligament ruptures. Am. J. Sports. med. 13: 183-187, 1985.

6) O'donoghue, D. H. et al.: An analysis of end results of surgical treatment major injuries to the ligaments of the knee. J. Bone Joint Surg. 37-A : 113, 1955.

7) O'donoghue, D. H. et al. : Repair and reconstruction of the anterior cruciate ligament in dogs. J. Bone Joint Surg. 53-A : 710-718, 1971.

8) O'donoghue, D. H. et al.: Repair of the anterior cruciate ligament in dogs. J. Bone Joint Surg. 48-A : 503-519, 1966.

9) O'donoghue, D. H. et al.: Surgical treatment of fresh injuries to the major ligaments of the knee. J. Bone Joint Surg. 32-A : 721-738, 1950.

10) Ogata, K. et al.: The intra-articular effect of various postoperative managements following knee ligament repair. Clin. Orthop. 150 : 271-276, 1980.
質 問国立別府病院 岡㠃 啓治

(1) 新鮮 ACL 損傷に対する一次修復術(とくにスポ ーツ選手において）は, 再建術と比較して後療法プロ グラムの遅れや, 可動域, 筋力などの術後成績はどう であったのか.

(2) 一次修復の際の皮切, 関節内への進入路はどう するのか. 近位部には割と大きく開けるのか.

\section{解 答福岡大学 古賀 哲二}

(1) 勒帯再建術との比較は行っていない. 現在では, レベルの高いスポーツ選手は, 確実で後療法が早期に 行える，一次再建術の適応と考えている.

(2) 皮切は, 内側傍膝蓋アプローチを用いているが 最近では, 出来る限り小さく行っている.
質 問 九州労災病院 桑野 正
術後の後療法について
(1) ギプス固定の期間
(2) 装具を使用しているか
(3) 荷重の時期

\section{解 答} 福岡大学 古賀 哲二

以前は 6 週間ギプス固定で筋力訓練も消極的であっ たが, 最近では, 2 週間ギプス固定後, 膝装具をつけ, CPM にて ROM 改善を行うと共に筋力訓練を積極的に 行っている.

\section{質 問熊本大学 久保田健治}

ACL 実質部の損傷に対する一次修復術の成績は不安 定で, 最近は行われていないのが一般的だと思うので すが, 先生方の症例でも, 客観的な安定性の獲得にお いては不十分なようです. 今後も一次修復を続けて行 っていかれるつもりでしょうか.

\section{解 答福岡大学 古賀 哲二}

ACL 実質部，とくに中央部の mop end 状の断裂は 成績が悪いと思われる。これらに対しては補強または 一次再建術の適応と考えている。

意 見 九州労災病院 井原 秀俊

$\mathrm{ACL}$ 新鮮損傷例について, 最近では手術をしなく, PCLの演題で述べたような, 保存的修復で割と良い結 果を得ている. 参考にして下さい. 